\title{
Prediction equations for the energy values of soybean meal for pigs at the growing phase with ex-post validation ${ }^{1}$
}

\author{
Equações de predição dos valores energéticos do farelo de soja para suínos em \\ crescimento com validação ex post
}

\author{
Everardo Ayres Correia Ellery², Pedro Henrique Watanabe ${ }^{2 *}$, Teresinha Marisa Bertol ${ }^{3}$, Ednardo Rodrigues \\ Freitas $^{2}$ e Germano Augusto Jerônimo Nascimento ${ }^{2}$
}

\begin{abstract}
The aim of this study was to determine and validate prediction equations for digestible (DE) and metabolizable energy (ME) of soybean meal for growing pigs. The prediction equations were developed using data from chemical composition, digestibility and metabolizability of soybean meal samples $(n=25)$ evaluated in essays at Embrapa Suínos e Aves. The equations were estimated through regression analysis, using the REG procedure of SAS and adjusted $\mathrm{R}^{2}$ was the criterion of choice to select the best models. Two equations were estimated for DE and two for ME. To validate the equations, one experiment with two essays was performed to determine the values of DE and ME of five samples of soybean meal. In each essay, 24 growing pigs with an initial weight of $54.20 \pm 1.28 \mathrm{~kg}$ at first and $54.60 \pm 2.26 \mathrm{~kg}$ at second essay, were sorted in a complete randomized block design with 6 treatments ( 1 reference diet and 5 test diets) and 4 replicates. Considering the lowest prediction error $\left(\mathrm{e}_{\mathrm{p}}\right)$, the equations to predict the $\mathrm{DE}$ and $\mathrm{ME}$ of soybean meal were: $\mathrm{DE}=48153-1586.1(\mathrm{~PB})+744.5(\mathrm{EE})+363.6(\mathrm{FB})$ $-1398.3(\mathrm{MM})+15.5\left(\mathrm{~PB}^{2}\right)-170.8\left(\mathrm{EE}^{2}\right)-29.3\left(\mathrm{FB}^{2}\right)+5.4\left(\mathrm{FDA}^{2}\right)-2.5\left(\mathrm{FDN}^{2}\right)+90.6\left(\mathrm{MM}^{2}\right)-8.2(\mathrm{EEFDA})+33(\mathrm{EEFDN})$, with $\mathrm{R}^{2}=0.88$ and $\mathrm{e}_{\mathrm{p}=} 2.32$ and $\mathrm{ME}=12692-2397.7(\mathrm{MM})-56.8\left(\mathrm{EE}^{2}\right)+164.9\left(\mathrm{MM}^{2}\right)-102.2(\mathrm{EEFB})-12.25(\mathrm{EEFDA})$ $+67.6(\mathrm{EEFDN})+5.5(\mathrm{PBFB})-2.9(\mathrm{PBFDN})$ with $\mathrm{R}^{2}=0.65$ and $\mathrm{e}_{\mathrm{p}}=1.69$. Based on the chemical composition data and correlations, it was possible to establish prediction equations for the values of digestible and metabolizable energy of soybean meal for pigs, being necessary validation for greater accuracy of the models.
\end{abstract}

Key words: Digestible energy. Mathematical models. Metabolizable energy. Protein feedstuffs.

RESUMO - Objetivou-se determinar e validar equações de predição para energia digestível (ED) e metabolizável (EM) do farelo de soja para suínos em crescimento. Foram utilizados dados de composição química, digestibilidade e metabolizabilidade de amostras de farelo de soja $(n=25)$, avaliadas em ensaios realizados na Embrapa Suínos e Aves. As equações foram estimadas por meio da análise de regressão, utilizando-se o procedimento REG do pacote estatístico SAS, e o $\mathrm{R}^{2}$ ajustado para selecionar os melhores modelos. Foram estimadas duas equações para ED e duas para EM. Para a validação das equações, foi realizado um experimento composto por dois ensaios, para a determinação dos valores de ED e EM de amostras do farelo de soja ( $n=5$ ). Em cada ensaio, 24 leitões machos castrados, com peso inicial de 54,20 \pm 1,28 kg no primeiro e 54,60 $\pm 2,26$ $\mathrm{kg}$ no segundo, foram distribuídos em delineamento em blocos ao acaso, com 6 tratamentos (1 ração referência e 5 rações testes) e 4 repetições por tratamento. Considerando-se o menor erro de predição ( $\mathrm{e}_{\mathrm{p}}$ ), as equações que melhor se ajustaram para predição dos valores ED e EM do farelo de soja foram: $\mathrm{ED}=48153$ - 1586,1(PB) + 744,5(EE) + 363,6(FB) - 1398,3 $(\mathrm{MM})+15,5\left(\mathrm{~PB}^{2}\right)-170,8\left(\mathrm{EE}^{2}\right)-29,3\left(\mathrm{FB}^{2}\right)+5,4\left(\mathrm{FDA}^{2}\right)-2,5\left(\mathrm{FDN}^{2}\right)+90,6\left(\mathrm{MM}^{2}\right)-8,2(\mathrm{EEFDA})+33(\mathrm{EEFDN})$, com R${ }^{2}=$ 0,88 e e $\mathrm{p}_{\mathrm{p}} 2,32, \mathrm{EM}=12692-2397,7(\mathrm{MM})-56,8\left(\mathrm{EE}^{2}\right)+164,9\left(\mathrm{MM}^{2}\right)-102,2(\mathrm{EEFB})-12,25(\mathrm{EEFDA})+67,6(\mathrm{EEFDN})+$ 5,5(PBFB) - 2,9(PBFDN) com $\mathrm{R}^{2}=0,65$ e e $=1,69$. A partir dos dados de composição química e das correlações existentes, foi possível estabelecer equações de predição para os valores de energia digestível e metabolizável do farelo de soja para suínos, sendo a validação necessária para maior acurácia dos modelos.

Palavras-chave: Alimento proteico. Energia digestível. Energia metabolizável. Modelos matemáticos.

\footnotetext{
DOI: $10.5935 / 1806-6690.20150076$

* Autor para correspondência

${ }^{1}$ Recebido para publicação em 17/03/2014, aprovado em 27/07/2015

Parte da Dissertação de Mestrado em Zootecnia do primeiro autor apresentada na Universidade Federal do Ceará; pesquisa financiada pela Embrapa 2Departamento de Zootecnia, Centro de Ciências Agrárias, Universidade Federal do Ceará (UFC). Av. Mister Hull, 2977, Bloco 808,

Fortaleza - CE, Brasil,60440-900, everardo.ellery@zootecnista.com.br, pedrowatanabe@ufc.br, ednardo@ufc.br, germanoaugusto@ufc.br ${ }^{3}$ Embrapa Suínos e Aves, Rodovia BR-153, km 110, Distrito de Tamanduá, Caixa Postal: 21, Concórdia-SC, Brasil, 89.700-000, teresinha. bertol@embrapa.br
} 


\section{INTRODUCTION}

The energy content of any feedstuff comprises the results of the oxidation of nutrients during animal metabolism. Among the constituents of feed, the soluble carbohydrates, lipids, amino acids and part of the dietary fiber supply energy to the organism; but not all the energy produced by oxidation of the nutrients can be used (SAKOMURA; ROSTAGNO, 2007). Depending on chemical composition therefore, the ingredients used in the formulation of diets for pigs may have varying energy values, and it is important to evaluate them in order to provide proper balance in the diets (NASCIMENTO et al., 2011). However, the efficiency of the method for formulating the diet is dependent on the accuracy with which the energy of the feed is determined (SILVA et al., 2003).

Biological trials aimed at analysing the digestibility and metabolizability of the nutrients and energy of any feed or ingredient, are shown to have a high degree of reliability, but they are costly and time-consuming. Thus, indirect methods, such as determination of the energy values of feeds by means of prediction equations, are low-cost alternatives when applied to specific feedstuffs (NOBLET; PEREZ, 1993).

Unlike studies to determine prediction equations for energy values of maize for pigs, where there is a diversity of research, for soybean meal reports are scarce and are mostly non-specific, being in general for protein feedstuffs of plant origin (NOBLET; PEREZ, 1993), or involving the use of indirect variables (KANG et al., 2004). Despite being primarily a source of protein in feed, soybean meal also contributes with an average of $20 \%$ of the energy value in diets for pigs at the growing phase; the energy content may vary due to processing of the soybean, residual oil content, protein quality and fiber content.

As the soybean meal is obtained from processing soybean, the range of values for the analytical parameters of experimental samples makes it difficult to predict energy values, resulting in regression coefficients with high standard deviations and low reliability (OST et al., 2005). In addition, few studies have been reported on the applicability of the equations that have been developed, and it is difficult to know the degree of confidence to be held in the equations currently available. As not all attempts to relate chemical composition and energy have been successful, and many prediction equations do not respond satisfactorily when tested with independent data (SIBBALD, 1982), the validation of prediction equations by means of statistical tools such as autocorrelation analysis of the prediction errors, and cross-correlation analysis between input and output data (AGUIRRE, 2004) seeks to increase the accuracy and precision of the prediction models.

Taking into account the information exposed above, the aim of the present work was to determine prediction equations for estimating values for the digestible and metabolizable energy in soybean meal for growing pigs, with subsequent validation based on the lowest prediction error.

\section{MATERIAL AND METHODS}

The information used in this study was obtained from data for the nutrient digestibility and metabolizable energy of different samples of soybean meal, determined in trials employing the total collection of faeces and urine, and conducted in the last two decades at the Experimental Facility for Metabolism in Pigs, of Embrapa Suínos e Aves, located in Concórdia, in the State of Santa Catarina, Brazil.

Data from 29 samples of soybean meal were recorded on a spreadsheet, including all the nutritional information for the samples and energy values. After cataloguing the data, the information was selected, analysed and then compared with values in the Tabelas Brasileiras para Aves e Suínos (ROSTAGNO et al., 2011.) and the NRC (2012), only considering those with information on crude protein (CP), ether extract (EE), mineral matter (MM), crude fibre (CF), neutral detergent fibre (NDF) and acid detergent fiber (ADF), as well as values for digestible energy (DE) and metabolizable energy (ME) for pigs at the growing phase. Of the 29 samples of soybean meal in the database, 25 were selected to obtain the prediction equations for estimating the values of DE and ME.

Pearson correlations were estimated (DRAPER; SMITH, 1981) to clarify the structure of the relationship among the variables under study, using the CORR procedure of the SAS statistical software (2009).

The prediction equations were estimated by regression analysis, using the REG procedure of the SAS software (2009). The adjusted $\mathrm{R}^{2}$ was the choice criterion for selecting the best models. Among the equations that had a higher adjusted $\mathrm{R}^{2}$, the final model was the one that included the variables of greatest interest, including interactions among the variables for a better fit of the equations. Two models were selected for DE and two models for ME, and subsequently validated.

For validation of the prediction equations, two metabolism trials were carried out to determine the values for digestible and metabolizable energy in five samples of 
soybean meal. In each trial, 24 barrows were used, from the crossing of MS-115 males and F1 females (Landrace $\mathrm{x}$ Large White), with an initial weight of $54.20 \pm 1.28 \mathrm{~kg}$ in the first and $54.60 \pm 2.26 \mathrm{~kg}$ in the second; animals were housed in cages for metabolic studies. A randomized block design was used to control the differences in initial weight, with six treatments and four replications per treatment in each trial; the experimental unit consisted of one animal.

The treatments comprised a reference diet and five test diets composed of $70 \%$ of the reference diet and $30 \%$ soybean meal. The reference diet (Table 1) was formulated to meet the minimum nutritional requirements of castrated male pigs with a live body weight of $50-70 \mathrm{~kg}$ and a high genetic potential, as per Rostagno et al. (2011).

Each trial lasted 12 days, with the first seven for adapting the animals to the cages and determining feed intake, and the last five for collecting faeces and urine. Feeding was carried out twice a day, at 08 a.m. and 02 p.m. After 30 minutes from the start of feeding, the leftovers were collected and weighed, thereby determining the amount ingested. Water was provided ad libitum after each feeding.

The amount of feed provided during the period of faeces collection was set according to the lowest consumption obtained during the initial seven days, based on the metabolic weight $\left(\mathrm{kg}^{0.75}\right)$ of each experimental unit. Ferric oxide $\left(\mathrm{Fe}_{2} \mathrm{O}_{3}\right)$ was used as a faecal marker in the proportion of $0.5 \%$, to determine the beginning and the end of the collection period. Total collection of the faeces was carried out in plastic bags twice a day, weighed and stored in a freezer at $-8{ }^{\circ} \mathrm{C}$ for later analysis. The urine was collected once a day, in plastic buckets containing a $20 \mathrm{~mL} \mathrm{1:1} \mathrm{solution} \mathrm{of} \mathrm{distilled} \mathrm{water} \mathrm{and} \mathrm{hydrochloric}$ acid $(2 \mathrm{~N})$, so as not to allow the loss of nitrogen or the proliferation of bacteria and fungi. The volume of urine produced was measured, and a $20 \%$ aliquot removed and stored in a freezer.

At the end of the experiment, the faeces and urine of each animal were unfrozen and homogenized to get a sample for each animal. Portions of the faeces were predried in a forced air circulation oven at $55{ }^{\circ} \mathrm{C}$ for $72 \mathrm{~h}$, and then ground in a knife mill with a $1 \mathrm{~mm}$ sieve. The urine samples were dried in petri dishes in a forced air circulation oven at $55^{\circ} \mathrm{C}$ for 72 hours, with the volume in the dishes being topped up every 24 hours. Samples of the feed and ingredients were ground, following the same procedures as described for the faeces.

Analysis of the chemical composition and gross energy (GE) of the ingredients, diets, faeces and urine was carried out at the Laboratory for Physical and Chemical Analysis of Embrapa Suínos e Aves (LAFQ), in
Table 1 - Centesimal, chemical and energy composition of the reference diet

\begin{tabular}{|c|c|}
\hline Ingredient $(\%)$ & Reference Diet \\
\hline Corn & 71.426 \\
\hline Soybean meal & 23.346 \\
\hline Degummed soybean oil & 1.520 \\
\hline Dicalcium phosphate & 0.896 \\
\hline Limestone & 0.696 \\
\hline Common salt & 0.404 \\
\hline L-Lysine $\mathrm{HCl}$ & 0.380 \\
\hline DL-Methionine & 0.118 \\
\hline L-Threonine & 0.110 \\
\hline L-Tryptophan & 0.014 \\
\hline Colistin sulphate & 0.020 \\
\hline Antioxidant $^{1}$ & 0.016 \\
\hline Cholin chloride & 0.010 \\
\hline Phytase & 0.010 \\
\hline Mycotoxin binder & 0.300 \\
\hline Mineral e vitamin supplement ${ }^{2}$ & 0.250 \\
\hline Industrial kaolin & 0.484 \\
\hline Total & 100.000 \\
\hline Metabolizable energy (kcal/kg) & $3,300.000$ \\
\hline Crude Protein $(\%)$ & 17.500 \\
\hline Available phosphorous (\%) & 0.400 \\
\hline Calcium (\%) & 0.720 \\
\hline Digestible lysine (\%) & 1.150 \\
\hline Digestible methionine + cystine $(\%)$ & 0.641 \\
\hline Digestible threonine $(\%)$ & 0.721 \\
\hline Digestible tryptophan (\%) & 0.195 \\
\hline
\end{tabular}

'butylhydroxytoluenw; ${ }^{2}$ Supplying the following quantities per kg of feed: $75 \mathrm{mg} \mathrm{Fe} ; 7.5 \mathrm{mg} \mathrm{Cu} ; 50 \mathrm{mg} \mathrm{Mn} ; 75 \mathrm{mg} \mathrm{Zn} ; 1.5 \mathrm{mg} \mathrm{Co} ; 0.5$ $\mathrm{mg} \mathrm{I} ; 0.25 \mathrm{mg} \mathrm{Se} ; 10000 \mathrm{UI}$ vit A; 1500 UI vit D3; $30 \mathrm{mg}$ vit E; 2.0 $\mathrm{mg}$ vit $\mathrm{K} 3 ; 2.0 \mathrm{mg}$ vit $\mathrm{B} 1 ; 5.0 \mathrm{mg}$ vit $\mathrm{B} 2 ; 3.0 \mathrm{mg}$ vit $\mathrm{B} 6 ; 30 \mathrm{mcg}$ vit B 12; $0.80 \mathrm{mg}$ folic acid; $12 \mathrm{mg}$ pantothenic acid; $30 \mathrm{mg}$ niacin

accordance with the AOAC (2005). Analysis of the neutral detergent fiber (NDF) and acid detergent fiber (ADF) was performed according to Van Soest et al. (1991). The gross energy (GE) of the ingredients, diets, faeces and urine was determined in a PARR Model 1241EA adiabatic bomb calorimeter. Values for the digestible and metabolizable energy of the soybean meal were determined from the equation proposed by Matterson et al. (1965).

After running the chemical analysis, the equations were validated. These were selected according to the highest 
adjusted $\mathrm{R}^{2}$, and submitted to regression analysis using the REG procedure of the SAS statistical software (2009). The lowest prediction error $\left(\mathrm{e}_{\mathrm{p}}\right)$ was used for criterion validation.

\section{RESULTS AND DISCUSSION}

Considering the low variation of soybean meal, values for the digestible and metabolizable energy of the samples had a coefficient of variation below $3 \%$ (Table 2). However, a greater variation was seen in the values of ether extract and fibrous fractions. The variability found for the level of ether extract in the soybean meal is due to the efficiency of the oilextraction process (OST et al., 2005; RIEGER et al., 2008), and may contribute to the variation found in the values of digestible and metabolizable energy.
For crude protein content (Table 2), the coefficient of variation was of $4.06 \%$ which can be attributed to changes when processing the soybean grains to obtain the meal. According to Zambom et al. (2001), when the protein value of the soybean grain is low, it is necessary to remove the soybean hull to increase the crude protein content, resulting in variations in the participation of the fibrous fractions, and confirmed by the difference found between the minimum and maximum values for $\mathrm{CF}, \mathrm{NDF}$ and ADF in the soybean meal.

A positive correlation was seen between the digestible energy and the values of metabolizable energy and ether extract (Table 3).

The interdependence between the apparent values for digestible and metabolizable energy shows that energy loss through the urine and fermentation processes, inherent

Table 2 - Energy values and average chemical composition of 25 samples of soybean meal (dry matter basis)

\begin{tabular}{lrcccc}
\hline \multicolumn{1}{c}{ Variable } & Mean & Standard deviation & Coefficient of variation & Minimum & Maximum \\
\hline DE (kcal kg) & 4084 & 94.81 & 2.32 & 3907 & 4233 \\
ME (kcal kg) & 3842 & 112.83 & 2.94 & 3607 & 4052 \\
CP $(\%)$ & 51.45 & 2.09 & 4.06 & 46.33 & 54.53 \\
EE (\%) & 2.10 & 0.72 & 34.29 & 1.04 & 3.77 \\
CF (\%) & 5.36 & 1.24 & 23.13 & 3.67 & 8.09 \\
ADF (\%) & 8.13 & 2.11 & 25.95 & 5.17 & 12.87 \\
NDF (\%) & 13.56 & 3.44 & 25.37 & 8.47 & 21.55 \\
MM (\%) & 6.71 & 0.59 & 8.79 & 5.48 & 8.48 \\
\hline
\end{tabular}

DE: digestible energy (kcal/kg); ME: metabolizable energy (kcal/kg); CP: crude protein (\%); EE: ether extract (\%); CP: crude fiber (\%); ADF acid detergent fiber (\%); NDF: neutral detergent fiber (\%); MM: mineral matter (\%)

Table 3 - Correlation coefficients between the variables of the chemical composition and the energy values of the soybean meal

\begin{tabular}{|c|c|c|c|c|c|c|c|c|}
\hline & $\mathrm{DE}$ & $\mathrm{ME}$ & $\mathrm{CP}$ & $\mathrm{EE}$ & $\mathrm{CF}$ & $\mathrm{ADF}$ & NDF & MM \\
\hline $\mathrm{DE}$ & 1.000 & & & & & & & \\
\hline ME & $0.633 * *$ & 1.000 & & & & & & \\
\hline $\mathrm{CP}$ & -0.244 & -0.132 & 1.000 & & & & & \\
\hline $\mathrm{EE}$ & $0.451 *$ & 0.217 & $-0.665 * *$ & 1.000 & & & & \\
\hline $\mathrm{CF}$ & -0.046 & 0.045 & -0.335 & -0.177 & 1.000 & & & \\
\hline $\mathrm{ADF}$ & -0.104 & -0.147 & -0.232 & -0.206 & $0.775 * *$ & 1.000 & & \\
\hline $\mathrm{NDF}$ & -0.165 & 0.084 & $-0.503 * *$ & -0.030 & $0.764 * *$ & 0.349 & 1.000 & \\
\hline MM & $-0.435^{*}$ & -0.153 & 0.356 & -0.219 & -0.095 & -0.178 & 0.864 & 1.000 \\
\hline
\end{tabular}

DE: digestible energy (kcal/kg); ME: metabolizable energy (kcal/kg); CP: crude protein (\%); EE: ether extract (\%); CP: crude fiber (\%); ADF acid detergent fiber (\%); NDF: neutral detergent fiber $(\%)$; MM: mineral matter $(\%)$; *significant at $5 \%$ probability by t-test $(\mathrm{P}<0,05)$; ** significant at $1 \%$ probability by t-test $(\mathrm{P}<0,01)$ 
to metabolism of the nutrients present in soybean meal, is small, due to the protein quality of the ingredient being evaluated. Thus, as this is a protein concentrate being processed thermally, soybean meal may show a greater difference between the values for $\mathrm{DE}$ and $\mathrm{ME}$ when overheated, resulting in a loss of nutritional value and energy (MENDES et al., 2004), and a lower correlation between DE and ME. According to Pozza et al. (2008), the variability seen between the values of DE and ME can be attributed to the protein quality of the ingredient, so that when the protein is of low quality the ME decreases due to the amino acids not used in protein synthesis being catabolized and used as an energy source, while the nitrogen is excreted in the urine.

As to the positive correlation between $\mathrm{DE}$ and $\mathrm{EE}$, when considering the residual lipid content of the ingredient, the contribution of this fraction to the energy content of the soybean meal becames evident. According to Tucci et al. (2003), including soybean oil in the feed for non-ruminants increases the metabolizable energy content of the feed by about $9 \mathrm{kcal}$ per gram. According to the same authors, the reduction in fatty acid synthesis due to the extra-calorific effect of the oil, results in more energy being available to the processes of production.

The negative correlation between DE and MM $(\mathrm{P}<0.05)$ confirms the results reported in previous studies, in which large amounts of MM reduced energy usage by the animals (ADEDOKUN; ADEOLA, 2005; OLUKOSI; ADEOLA, 2009). In addition to its dilution effect, mineral matter can reduce the digestibility of some nutrients such as fats, due to the saponification process in the intestinal lumen, as well as by affecting the rate of passage of digesta or enhancing the interactions between minerals and other nutrients (NOBLET; PEREZ, 1993).

The variables used to fit the prediction equations to estimate the values of DE and ME in soybean meal for growing pigs were ether extract, mineral matter, crude protein, crude fiber, acid detergent fiber and neutral detergent fiber. Based on the nutritional composition of various ingredients, Just et al. (1984) observed that the best equations were estimated from the values for $\mathrm{CP}$, $\mathrm{CF}$, nitrogen-free extract, NDF, gross energy and organic matter, further stating that including ADF would give better prediction equations. Similarly, based only on the chemical composition of the feed, Noblet and Perez (1993) found that the MM, CP, EE and dietary fiber were the best predictors of digestible and metabolizable energy values.

It is important to point out that, based on the components measured in each analysis to determine the fiber, the differences found among fractions measured by each of the methodologies result in the participation of all the values obtained for the fibrous components in the equations; thus, the methods of determining the fibrous fraction in the feed are not independent of each other (ANDERSON et al., 2011). Accordingly, Noblet and Perez (1993), supported by Just et al. (1984), observed that components of the cell wall were the best predictors for the prediction equations of various ingredients, further stating that greater accuracy could be obtained from the fractionation of the NDF in hemicellulose, cellulose and lignin. In turn, Kang et al. (2004) developed prediction equations to estimate the metabolizable energy in soybean meal for pigs with the inclusion of $\mathrm{ADF}$ and soluble carbohydrates.

According to Noblet and Perez (1993), it is thought that the choice of a prediction equation to estimate the values of digestible and metabolizable energy should be dependent on the cost of the analytical procedures involved and the accuracy of the prediction. Therefore, considering the values obtained for the adjusted $\mathrm{R}^{\mathbf{2}}$ in this study, the use of data from chemical analysis commonly carried out to determine the nutritional composition of feed, as well as the different correlations found among them as predictors, made it possible to determine the equations without the use of data from more costly analyses, such as that for gross energy.

The prediction equations with the best fit in to estimate the value of DE in soybean meal for growing pigs were:

$\mathrm{DE}_{1}=48153-1586.1(\mathrm{CP})+744.5(\mathrm{EE})+363.6(\mathrm{CF})$ $-1398.3(\mathrm{MM})+15.5\left(\mathrm{CP}^{2}\right)-170.8\left(\mathrm{EE}^{2}\right)-29.3\left(\mathrm{CF}^{2}\right)+$ $5.4\left(\mathrm{ADF}^{2}\right)-2.5\left(\mathrm{NDF}^{2}\right)+90.6\left(\mathrm{MM}^{2}\right)-48.2(\mathrm{EEADF})+$ $33\left(\right.$ EENDF), with $\mathrm{R}^{2}=0.88$ and adjusted $\mathrm{R}^{2}=0.77$;

$$
\begin{aligned}
& \mathrm{DE}_{2}=7414.9-903.4(\mathrm{MM})-88.2\left(\mathrm{EE}^{2}\right)-34.7\left(\mathrm{CF}^{2}\right) \\
& + \text { 9.6( }\left(\mathrm{ADF}^{2}\right)+58.4\left(\mathrm{MM}^{2}\right)-101.6(\mathrm{EECF})+72.4(\mathrm{EENDF}) \\
& +12.3(\mathrm{CPCF})-3.2(\mathrm{CPADF})-3(\mathrm{CPNDF}), \text { with an } \mathrm{R}^{2} \text { of } \\
& 0.86 \text { and adjusted } \mathrm{R}^{2}=0.75 .
\end{aligned}
$$

The equations with the best fit to predict the ME of soybean meal for growing pigs were:

$$
\mathrm{ME}_{1}=12692-2397.7(\mathrm{MM})-56.8\left(\mathrm{EE}^{2}\right)+
$$
$164.9\left(\mathrm{MM}^{2}\right)-102.2(\mathrm{EECF})-12.25(\mathrm{EEADF})+$ $67.6(\mathrm{EENDF})+5.5(\mathrm{CPCF})-2.9(\mathrm{CPNDF})$, with an $\mathrm{R}^{2}$ of 0.65 and adjusted $\mathrm{R}^{2}=0.48$;

$$
\mathrm{ME}_{2}=10963+37.7(\mathrm{CP})+309.4(\mathrm{CF})-
$$
2450.7(MM) - 67.1( $\left.\mathrm{EE}^{2}\right)+167.9\left(\mathrm{MM}^{2}\right)-111.2(\mathrm{EECF})$ - 13.2(EEADF) + 76.7(EENDF) - 3.3(CPNDF), with an $\mathrm{R}^{2}=0.66$ and adjusted $\mathrm{R}^{2}=0.46$.

In Table 4 can be found the values for dry matter (DM), gross energy (GE), digestible energy (DE), metabolizable energy (ME), crude protein $(\mathrm{CP})$, ether extract (EE), crude fiber (CF), acid detergent fibre (ADF), neutral detergent fiber (NDF) and mineral matter (MM), of the five samples of soybean meal used in the metabolism 
trials to validate the prediction equations. All the values found are within the range of the values obtained in the soybean meal samples compiled at the beginning of the experiment, allowing all the samples to be included in the validation.

Unlike the present study, the prediction equations found in the literature for the various raw materials include a limited number of variables (POZZA et al., 2008a; CASTILHA et al., 2011), due to the shorter time required to perform the analyzes and ease of use (POZZA et al., 2008b). As a result, there is great interest in the use of prediction equations for the digestible and metabolizable energy in feed, which comprise one or more combinations of chemical composition variables (COSTA et al., 2005).

However, generating equations does not imply that they will predict values more accurately, being necessary to validate the equations, reporting the prediction error or residue that is used to estimate the mathematical models and the coefficients of determination $\left(\mathrm{R}^{2}\right.$ and adjusted $R^{2}$ ). The coefficients of determination $\left(R^{2}\right)$, prediction error and accuracy obtained for the proposed models are shown in Table 5.

The equations with the best fit in predicting the values for digestible and metabolizable energy in soybean meal for growing pigs, with the lowest prediction error $\left(e_{p}\right)$ were respectively:

$\mathrm{DE}_{1}=48153-1586.1(\mathrm{CP})+744.5(\mathrm{EE})+363.6(\mathrm{CF})$ $-1398.3(\mathrm{MM})+15.5\left(\mathrm{CP}^{2}\right)-170.8\left(\mathrm{EE}^{2}\right)-29.3\left(\mathrm{CF}^{2}\right)+$ $5.4\left(\mathrm{ADF}^{2}\right)-2.5\left(\mathrm{NDF}^{2}\right)+90.6\left(\mathrm{MM}^{2}\right)-48.2(\mathrm{EEADF})+$ $33(\mathrm{EENDF})$, with $\mathrm{R}^{2}=0.88$ and $\mathrm{e}_{\mathrm{p}=} 2.32 \%$;

$\mathrm{ME}_{1}=12692-2397.7(\mathrm{MM})-56.8\left(\mathrm{EE}^{2}\right)+$ $164.9\left(\mathrm{MM}^{2}\right)-102.2(\mathrm{EECF})-12.25(\mathrm{EEADF})+$ 67.6(EENDF $)+5.5(\mathrm{CPCF})-2.9(\mathrm{CPNDF})$, with an $\mathrm{R}^{2}$ of 0.65 and $\mathrm{e}_{\mathrm{p}}=1.69 \%$.

Although several studies have been carried out to determine the relationship between the chemical composition and energy value of feed (ZONTA et al., 2006; POZZA et al., 2008a; POZZA et al., 2008b; SIQUEIRA et al., 2011), few have reported on the applicability of the equations, making it difficult to know the degree of confidence that can be achieved with the equations available. Thus, $\mathrm{R}^{2}$ values would allow estimation of the fit of the equation to the original data, but would not necessarily indicate the accuracy of the equation in predicting the energy values for raw materials or feed in other than the original data.

The ability for generalization of a prediction equation must therefore be validated by using a new set

Table 4 - Chemical composition and energy values of the five samples of soybean meal used to validate the equations

\begin{tabular}{lccccccccc}
\hline $\begin{array}{c}\text { Soybean meal } \\
\text { sample }\end{array}$ & DM & DE & ME & CP & EE & CF & ADF & NDF & MM \\
\hline 1 & 90.66 & 3815 & 3718 & 52.63 & 1.80 & 4.33 & 7.09 & 10.59 & 7.59 \\
2 & 89.77 & 4025 & 3924 & 50.01 & 2.24 & 6.05 & 8.79 & 13.51 & 7.34 \\
3 & 86.70 & 3993 & 3907 & 49.39 & 1.08 & 7.59 & 12.48 & 17.52 & 6.23 \\
4 & 88.16 & 4139 & 4007 & 53.47 & 2.08 & 4.16 & 6.08 & 10.42 & 5.94 \\
5 & 88.67 & 4108 & 4026 & 52.04 & 1.47 & 7.47 & 11.14 & 12.50 & 6.34 \\
\hline
\end{tabular}

DM: dry matter; DE: digestible energy (kcal/kg); ME: metabolizable energy (kcal $/ \mathrm{kg})$; CP: crude protein (\%); EE: ether extract (\%); CF: crude fiber (\%); ADF: acid detergent fiber (\%); NDF: neutral detergent fiber (\%); MM: mineral matter (\%)

Table 5 - Coefficients of determination, prediction error and accuracy of the prediction equations to estimate the energy values of soybean meal for growing pigs

\begin{tabular}{lccrcc}
\hline \multicolumn{1}{c}{ Equation } & $\mathrm{R}^{2}$ & Adjusted $\mathrm{R}^{2}$ & Pr $>\mathrm{F}$ & Prediction error $(\%)$ & Accuracy $(\mathrm{kcal} \mathrm{kg})$ \\
\hline $\mathrm{DE}_{1}$ & 0.88 & 0.77 & 0.0006 & $2.32 \pm 1.10$ & $93.1 \pm 44.5$ \\
$\mathrm{DE}_{2}$ & 0.86 & 0.75 & 0.0002 & $2.43 \pm 1.96$ & $96.9 \pm 77.2$ \\
$\mathrm{ME}_{1}$ & 0.65 & 0.48 & 0.01 & $1.69 \pm 1.42$ & $-9.4 \pm 92.7$ \\
$\mathrm{ME}_{2}$ & 0.66 & 0.46 & 0.02 & $2.93 \pm 2.08$ & $-106.7 \pm 100.8$ \\
\hline
\end{tabular}


of data, in order to estimate the accuracy of the model. Accordingly, the prediction error can be used as a way of validating the proposed prediction equations, as it determines the residual error of the model, excluding the error attributed to mean bias (MEYER et al., 2006).

In this study, the equations that displayed the lowest prediction error and the greatest accuracy to estimate the values of digestible energy, was DE1, with a prediction error $\left(\mathrm{e}_{\mathrm{p}}\right)$ of $2.32 \%$, and for metabolizable energy, it was the ME1, with $\mathrm{e}_{\mathrm{p}}$ of $1.69 \%$. It should be understood that a small reduction in accuracy is acceptable if it is possible to establish relationships that indicate that the energy values of the feed may be estimated from chemical measurements.

Given the equations and prediction errors obtained, determination of the energy values of soybean meal based on bromatological composition resulted in one equation to estimate the value of $\mathrm{DE}$ and another to estimate ME value, allowing their application since they have been validated.

\section{CONCLUSIONS}

1. From the chemical composition and correlation between the variables, it was possible to establish prediction equations to estimate the values of digestible and metabolizable energy of soybean meal for pigs;

2. Validation of the equations with a new set of data results in higher accuracy of the obtained models.

\section{REFERENCES}

ADEDOKUN, S.A.; ADEOLA, O. Metabolizable energy value of meat and bone meal for pigs. Journal of Animal Science, v. 83, p. 2519-2526, 2005.

AGUIRRE, L. Introdução à identificação de Sistemas: técnicas lineares e não-lineares aplicadas a sistemas reais. Belo Horizonte, Minas Gerais, 2.ed., 2004. 714p.

AOAC. Official methods of analysis of the Association Analytical Chemists. 18.ed. Gaithersburg, Maryland, 2005.

CASTILHA, L.D. et al. Modelos matemáticos para predição dos valores energéticos do milho para suínos. Revista Brasileira de Saúde e Produção Animal, v. 12, p. 456-467, 2011.

COSTA, M.A.L. et al. Validação das Equações do NRC (2001) para Predição do Valor Energético de Alimentos nas Condições Brasileiras. Revista Brasileira de Zootecnia, v. 34, n. 1, p. $280-$ 287, 2005.

DRAPER, N.R.; SMITH, H. Applied regression analysis. 2.ed. New York: John Wiley, 1981. 709p.
JUST, A.; JORGENSEN, H.; FERNANDEZ, J.A. Prediction of metabolizable energy for pigs on the basis of crude nutrients in the feeds. Livestock Production Science, Amsterdam, v. 11, p. 105-128, 1984.

MATERSON, L.D.; POTTER, L.M.; STUTZ, M.W. The metabolizable energy of feed ingredients for chickens. Research Report, v. 7, n. 1, p. 11-14, 1965.

MENDES, W.S. et al. Composição química e valor nutritivo da soja crua e submetida a diferentes processamentos térmicos para suínos em crescimento. Arquivo Brasileiro de Medicina Veterinária e Zootecnia, v. 56, n. 2, p. 207-213, 2004.

MEYER, P.M. et al. Validação de modelos de predição de nitrogênio uréico no leite, estimando-se o consumo individual pelo consumo do rebanho. Acta Scientiarum - Animal Sciences, Maringá, v. 28, n. 1, p. 73-79, 2006

NASCIMENTO, G.A.J. et al. Equações de predição para estimar os valores da EMAn de alimentos protéicos para aves utilizando a meta-análise. Revista Brasileira de Zootecnia, Viçosa, v. 40, n. 10, p. 2172-2177, 2011.

NATIONALRESEARCHCOUNCIL. Nutrient requirements of swine. 11th rev. ed. Washington: National Academic, 2012. 400p.

NOBLET, J.; PEREZ, J.M. Prediction of digestibility of nutrients and energy values of pig diets from chemical analysis. Journal of Animal Science, v. 71, p. 3389-3398, 1993.

OLUKOSI, O.A.; ADEOLA. O. Estimation of the metabolizable energy content of meat and bone meal for swine, 2009. Journal of Animal Science, v. 87, p. 2590-2599, 2009.

OST, P.R. et al. Valores energéticos de sojas integrais e de farelos de soja, determinados com galos adultos e por equações de predição. Ciência e Agrotecnologia, v. 29, n. 2, p .467-475, 2005.

POZZA, P.C. et al. Composição química, digestibilidade e predição dos valores energéticos da farinha de carne e ossos para suínos. Acta Scientiarum - Animal Science, v. 30, n. 1, p. 3340, 2008a.

POZZA, P.C. et al. Determinação e predição dos valores de energia digestível e metabolizável da farinha de vísceras para suínos. Revista Brasileira de Saúde e Produção Animal, v. 9, n. 4, p. 734-742, 2008b.

RIEGER, C. et al. Características químicas e valores energéticos de farelos de soja do oeste e sudoeste do Paraná. Ciência Rural, Santa Maria, v.38, n. 1, p. 266-269, 2008.

ROSTAGNO, H.S. et al. Tabelas brasileiras para aves e suínos: composição de alimentos e exigências nutricionais. 3.ed. Viçosa: Universidade Federal de Viçosa, 2011. 252p.

SAKOMURA, N.K.; ROSTAGNO, H.S. Métodos de Pesquisa em Nutrição de Monogástricos. Jaboticabal: FUNEP, 2007, 283 p.

SAS INSTITUTE. SAS: user's Guide. Version 9.2. Cary: SAS Institute, 2009. 7869p. 
SIBBALD, I.R. Measurement of bioavailable energy in poultry feedingstuffs: a review. Canadian Journal of Animal Science, v. 62 , p. $983-1048,1982$.

SILVA, J.H.V. et al. Energia metabolizável de ingredientes determinada com codornas japonesas (Coturnix coturnix japonica). Revista Brasileira de Zootecnia, v. 32, n. 6, p. 19121918, 2003.

SIQUEIRA, J.C. et al. Equações de predição da energia metabolizável da torta de babaçu para frangos de corte. Revista Brasileira de Saúde e Produção Animal, Salvador, v. 12, n .4, p. 1016-1025, 2011.

TUCCI, F.M. et al. Determinação da composição química e dos valores energéticos de alguns alimentos para aves. Acta Scientiarum Animal Sciences, v. 25, n. 1, p. 85-89, 2003.
VAN SOEST, P.J.; ROBERTSON, J.B.; LEWIS, B.A. Methods for dietary fiber, neutral detergent fiber, and nonstarch polysaccharides in relation to animal nutrition. Journal Dairy Science, v. 74, p. 3583-3597, 1991.

ZAMBOM, M.A. et al. Valor nutricional da casca do grão de soja, farelo de soja, milho moído e farelo de trigo para bovinos. Acta Scientiarum - Animal Science, Maringá, v. 23, n. 4, p. 937 943, 2001.

ZONTA, M.C.M. et al. Energia metabolizável de farinhas de soja ou produtos de soja, determinada pelo método de coleta total e por equações de predição. Archivos de Zootecnia, v. 55, n. 209, p. 21-30, 2006.

ZONTA, M.C.M. et al. Energia metabolizável de ingredientes proteicos determinada pelo método de coleta total e por equações de predição. Ciência e Agrotecnologia., v. 28, p. 1400-1407, 2004. 